\title{
MALAT1/TFEB Fusion Gene
}

National Cancer Institute

\section{Source}

National Cancer Institute. MALAT1/TFEB Fusion Gene. NCI Thesaurus. Code C99829.

A fusion gene that results from a chromosomal translocation $t(6 ; 11)(p 21 ; q 12)$ which fuses the MALAT 1 gene to the entire coding sequence of the TFEB gene. This rearrangement is associated with renal cell carcinoma. 